\title{
Psychological Poetic Drama in Modern Arabic Poetry and Dialogue with Myth
}

\author{
Mahmud Na'amneh \\ Saleem Abu Jaber
}

Psychological poetic drama in Arabic has been influenced by modern theories of psychology. Plays of this kind use mythical characters with which the reader interacts and which take on specific, fixed features in the course of reading, so that eventually the reader is able to foresee what this figure well say or do (the figure's behavior), whatever its degree of development. ${ }^{1}$ Psychological plays lack the sequence of dramatic events that one is accustomed to see in traditional drama. These events help us to analyze a protagonist's mental state better than disjoint events. In this connection we shall examine the psychological poetic drama of the Iraqi poet Sa'dī Yūsuf, who used ancient Iraqi myths. His plays possess unique features and their own special poetics that can help readers to more easily follow the mental state of the mythological figures used in them.

Arab poets began to produce poetic drama long after this genre came into use elsewhere. ${ }^{2}$ However, it provided Arab poets with a very good medium with which to express life's complexities. Poetic drama in the past used figures from ancient Greek mythology; ${ }^{3}$ therefore the mythological figures used in contemporary Arabic poetic plays may be considered a kind of cultural extension of this. Sa'dì Yūsuf in his play 'Indamā fì al-a'ālī (When Above, a title taken from the opening words of the Babylonian myth of creation) used Babylonian mythology and gave it a very marked presence, transforming its meanings in the play so that they came to express the social and political problems experienced by Iraq today. The play was a reaction to social, political and dramatic issues (meta-drama), formulated in the shape of a foreign myth. ${ }^{4}$ In the 1970s literary criticism ignored Iraqi drama both because of its language (it used the colloquial) ${ }^{5}$ and its content (it usually dealt with the lower classes of society and showed off the bourgeoisie in an unflattering light). Furthermore, in the view of critics, such drama should have had connections to both what had been written outside the Arab world and to the heritage of the ancients. ${ }^{6}$ Thus what distinguishes Sa'dī Yūsuf's play is that it fulfills all these demands made by critics. It is written in high Standard Arabic, it deals with a topic that speaks

\footnotetext{
${ }^{1}$ For more on the characteristics of this genre of drama see: 'Anānī, 1985, 7-9.

${ }^{2}$ Iraqi drama went through a crisis because it polarized the public. This resulted in the public to abandon prose in favor of poetry, after Iraqi prose drama had failed to communicate its messages. For more on the crisis of drama and the polarization of its consumers in Iraq see: Tam`a, 1988.

3 'Abd al-Wahhāb, 1985, 81.

${ }^{4}$ It may be argued that When Above is a meta-play, that is, a play that speaks about itself. Since in the myth of Gilgamesh he states himself that human creative writing is a substitute for immortality, Sa'dī Yūsuf clearly intends to speak here about the play, which substitutes for exile and the difficult political and social situation. On metadrama see the extensive study by Hājj, 2002; on society in Arabic poetic drama see Ahmad, 1982; and on the issues which Arabic poetic plays address see Ismāc̄ll, 1980.

${ }^{5}$ For more on drama in the Levant see Powers, 1990.

${ }^{6}$ See Sallūm, 1977-1987, 173-174.
} 
to every reader, and its makes use of ancient myth. In addition, as the present study argues, it constitutes a novel kind of poetic drama in the form of a psychological play, as we shall explain in detail below.

Drama in the Arab world and elsewhere used ancient Semitic and Greek legends, ${ }^{7}$ thus forming a unique bond with mythology. ${ }^{8}$ However, very few studies have dealt with the concept of "psychological play" as a new genre of poetic drama that utilizes ancient myths and that possesses its own characteristics and poetics. The few studies that do exist deal mostly with modern Western psychological poetic drama; none deal with its Arabic counterpart. ${ }^{9}$

Psychological drama is a modern development in the West, one that has even today not yet reached its definitive form but is still in the process of formation, crystallization and construction. The term "psychological drama" was invented in order to distinguish plays of this kind from the traditional classical kind. ${ }^{10}$

Plays of this genre made their appearance in the wake of the emergence of stream-ofconsciousness literature, ${ }^{11}$ according to which literary figures possess fixed, well-defined features that make it possible for the reader to foretell what that figure will say or do the moment he sees it or reads about it, irrespective of the extent of that figure's development. ${ }^{12}$

The characters in psychological drama have features of the kind that began to appear at the beginning of the twentieth century in James Joyce's and Virginia Wolff's stream-ofconsciousness novels and in the works of poets such as Thomas Eliot and Ezra Pound. For them the figures did not possess the kind of stability found in traditional literature; rather, they constantly changed and their depiction was based on what went through their minds. ${ }^{13}$ Despite this, psychological drama did not take hold ${ }^{14}$ until the end of the 1960 s and the beginning of the 1970s, after social and intellectual drama began to wane. ${ }^{15}$

What distinguishes psychological from traditional drama is that in the former the events are transported into the figures, whose inner selves are unbalanced. With respect to dramatic structure, in such plays there is almost no action in the traditional sense. In a traditional play things happen on stage in a sequential chronological and logical order and lead to a climax, dictated by the nature of the characters. In psychological plays, on the other hand, events do not unfold linearly or chronologically towards a point of crisis, but orbit in semicircles each of which consists of a moment in which two feelings or two thoughts confront each other. The reader thus cannot advance temporally with the events, nor does he move towards a specific moment in time. Rather, he circles with the feelings and thoughts until he returns to the point of origin, and in the second half of the circle he begins anew, eventually returning again to the starting point, and so on. The reader tries constantly to establish a relationship of some kind,

\footnotetext{
${ }^{7}$ On Arabic poetic drama, its evolution and dissemination, see al-Ahmad, 1982, 32-60. On the use of myths in Arabic poetic drama from its inception until the modernist period in literature see Badawī, 1998, 103-118.

8 'Anānī, 1985, 7.

9 The search for the self in Arabic drama has taken three directions: calling oneself and the political authority to account; return to and re-reading the ancient texts, in search of historical circumstances that could be compared to the present situation of the Arabs; and a call for finding a new mold for Arabic drama. See Hammūda, $1999,395$.

${ }^{10}$ For some of the features of this type of drama see 'Anānī, 1985, 7.

${ }^{11}$ On stream-of-consciousness see an extensive discussion in Ghanaim, 1987, 69-113; 1992.

12 ‘Anānī, 1985, 9.

13 ‘Anānī, 1985, 9.

14 On modern schools of drama see Șalīḥa, 1982.

15 'Anānī, 1985, 10.
} 
with which to begin an event of some kind, but then it is broken again. ${ }^{16}$ Thus it may be said that the afore-mentioned circles and semicircles compensate for the lack of action. In a psychological play they make us aware of the mental state of each figure, and thus enable us to approach their space.

Now we ask: What is the relationship between myth and psychological drama? The first thing that the reader notices in a psychological play that uses an ancient myth is the apprehension felt by the contemporary poet, which is identical to what the protagonist in the original legend felt, caused by a constant fear of the unknown, of fate, and of whatever is perceived as threatening one with death and oblivion. ${ }^{17}$ The apprehension which a psychological play that uses myth usually displays is the same apprehension from which the ancient mythological heroes suffered when they had to face the problems and complexities of their world.

The question which a psychological play presents is an existential one, that of an individual experiencing the suffering of his nation or, in other words, an individual suffering from a collective problem, so that his or her salvation or death means the salvation or death of everyone. It is an issue that is related to the figure's self, but at the same time it is related also to the collective, and is usually of a nationalist nature. ${ }^{18}$

Ancient myths, similarly, present us with an issue that affects an individual who represents a collective. This is the case also of Gilgamesh, whose search for the secret of immortality involves his own salvation but also that of the people of the ancient city of Uruk. This explains the relationship between ancient myth and modern psychological poetic drama.

In the work under discussion, a modern psychological play that uses an ancient myth and shows the influence of modern psychology, Sa'dī Yūsuf presents the difficulties he experienced in his life, using the myth as his medium of expression. This makes him unique among modern Arabic poets.

The appearance of psychological drama on the stage of modern literature has brought about the emergence of the kind of criticism called "the psychological approach to psychological drama". In this approach the critic may analyze a psychological play in order to derive information about the writer's mental state, or he may analyze all of a writer's plays, from which he draws general conclusions about his state; these conclusions may in turn then be used to explain this or that play by the writer. At other times the approach may involve the transfer of conclusions from the writer's personal life to a play or from his plays to his personal life, in the hope that such a comparison between the two may enable us to connect the writer's own psychological crises with those that are reflected in his plays. ${ }^{19}$

In psychological drama the protagonist's mental state is the dimension that is highlighted while other dimensions that readers have expected to encounter with respect to any stage figure are absent, such as physical features and sociological elements such as religion, culture and class. The psychological dimension is associated with an individual's temper and tendencies, imperfections, moral values, aims in life, failures, creativity, taste, ways of thought, introversion, sociability, struggle, surrender and complexes. ${ }^{20}$

\footnotetext{
16 Ibid., 10-11.

17 Shukrī, 1965, 169-178.

18 Sartre, 2008, 46-58; Makkāwī, 1995, 374-376; al-Ghadhāmī, 1993, 144-148.

19 'Alī, 1997, 142-143.

20 On the three dimensions and the contents of each in a play see al-Nādī, 1987, 46-48.
} 
In such a play we become acquainted with the poet's mental state as we follow the topics in the dialogues among the protagonists. These plays usually have an ending that is as strange as everything else in them, for obvious reasons: The semicircles that replace events in them make it nearly impossible for the reader to know what ending to expect; even if he tries to tie the last circle or semicircle to the other circles, the ending will in any case we unclear. ${ }^{21}$

Yūsuf Sa'dì decided to use this genre due to his belief that psychological drama was the best way to sow the seeds of rebellion in the minds of his viewers/readers in a mentally mature and dramatically indirect way, very different from what we are usually accustomed to see in traditional drama, and to mentally energize all their forces, instincts and tendencies. ${ }^{22} \mathrm{We}$ shall now proceed to analyze how Sa'dī Yūsuf does this by examining his poetry, specifically three dramatic scenes taken from his poetic collection Kull hānāt al-'ālam min Gilgamesh ilā Marrākish (All the World's Taverns from Gilgamesh to Marrakesh).

Yūsuf writes: ${ }^{23}$

\section{SCENE ONE}

(Siduri's tavern on the sea. Vines on a trellis. Siduri looks like Ishtar)

Gilgamesh enters (Long hair. Disheveled. Clothed in rough hides. Face parched by the sun. He looks like Enkidu the wild man).

Siduri (Sighs as she greets him):

Greetings to him who comes from a hard and long journey

Sit

I will give you refreshment

And the tavern wine

Gilgamesh (sits)

In these opening lines of the play Yūsuf presents a tavern by the sea, run by Siduri, a young woman with similarity to the goddess Ishtar. This information is presented in the form of the explanatory introduction to the scene of a play, which can prepare the reader for action taking place within the protagonists.

The same thing recurs in the second scene, where Gilgamesh enters, clothed in animal hides (indicating his boorishness and the difficult journey he had), his hair disheveled and his face burnt from exposure to the sun during his long journey. We are perhaps prepared for this by Yūsuf's comment that Gilgamesh's features are reminiscent of those of his friend Enkidu, so that we can empathize with this hero who experienced hardships on his way to Siduri's tavern. After this we are in a position to realize the nature of the struggle experienced by Gilgamesh, and can therefore understand his unbalanced behavior.

Gilgamesh arrives after a long journey, which has left its marks on him. His appearance is similar to that of Enkidu when he was a beast in the wild, disheveled and covered with dust. Siduri, the tavern keeper, welcomes him, realizing that he has a long journey behind him

\footnotetext{
21 'Anānī, 1985, 13-17.

22 On the way psychological drama emits notions of rejection and rebellion see al-Dālī, 1999, 211.

23 Yūsuf, 1992, 114.
} 
(perhaps because of his features, or perhaps because she knows that Gilgamesh was destined to come to her). She serves him personally and gives him her wine and her cup. ${ }^{24}$

This scene, too, prepares us for a dialogue between Gilgamesh and Siduri. The dialogue begins with Siduri's invitation to Gilgamesh to rest from the tribulations of his long travels. She offers him wine and whatever her tavern has to offer. Gilgamesh then sits.

In another scene we again encounter graphic and linguistic devices that Yūsuf uses and that can help us understand the psychological drama system. Among these devices is the information provided by the writer that perhaps cannot be deduced from the dialogue. The scene is possibly a means for understanding the internal dimension of the figure that is presented. Dialogue is another one of these devices.

In the second passage of the first scene Yūsuf says: ${ }^{25}$

How beautiful is this tavern

How sweet the cups

How splendid the vine trellises...

Siduri (smiling):

And what about me?

Gilgamesh:

I was speaking of you

Siduri:

Strange ...

Gilgamesh has not changed

In these lines Gilgamesh speaks to Siduri. He praises the beauty of her tavern's cups and trellises. Siduri asks him if she is not beautiful as well and Gilgamesh replies that in fact she was the intended object of his praise. Siduri is pleased and says "Gilgamesh has not changed", as if the text suggests that Gilgamesh is by nature a sly lover of beauty and women and here woos the tavern keeper Siduri, who explains that Gilgamesh is still the same lover of life as always, and still tries to attain immortality. We note that in these lines there is no action at all in the traditional sense; the narrative proceeds, but with no sequence of events.

In these lines Gilgamesh is amazed at the beauty of Siduri's tavern, the cups of wine and the vine trellises. These details are not found in the original text of the legend used by Yūsuf. Gilgamesh's amazement reflects his mental fatigue. He is apparently so exhausted that he acts as if he never saw such delights before, as if he never before drank wine. When Siduri smiles and asks him "what about me?", by which she means "Am I not beautiful as well?", Gilgamesh replies that he did in fact mean her and not literally what he had said before. Thereupon Siduri exclaims that Gilgamesh is still the same and has not changed. This reply, which is far from providing a complete explanation of what it is in Gilgamesh that does not change, enables us to surmise his cunning.

The admiration expressed by Gilgamesh in the lines quoted above helps us approach his personality and attempt to understand its mentality. We note that Gilgamesh, despite the hunger and hardships he experienced (at the physical level, during his exhausting journey, and

${ }^{24}$ Each scene is divided into sub-scenes, which will be called scenes here. 25 Yūsuf, 1992, 115. 
at the mental level, in the form of complex questions about death), sees the beauty in things and feels a measure of delight.

If we now go back to the original text of the Gilgamesh epic we find that Sa'di Yūsuf used some of its ideas while he modified others to make them fit the meanings that he has in mind. We read in the original text: 26

The tavern-keeper Siduri who lives by the seashore,

she lives...

the pot-stand was made for her, the golden fermenting vat was made for her.

She is covered with a veil ...

Gilgamesh was roving about...

wearing a skin,...

having the flesh of the gods in his body,

but sadness deep within him,

looking like one who has been traveling a long distance.

The tavern-keeper was gazing off into the distance,

puzzling to herself, she said,

wondering to herself:

"That fellow is surely a murderer(!)!

Where is he heading! ..."

As soon as the tavern-keeper saw him, she bolted her door,

bolted her gate, bolted the lock.

But at her noise Gilgamesh pricked up his ears,

lifted his chin (to look about) and then laid his eyes on her.

Gilgamesh spoke to the tavern-keeper, saying:

"Tavern-keeper, what have you seen that made you bolt

your door,

bolt your gate, bolt the lock!

if you do not let me in I will break your door, and smash

the lock!

... the wilderness."

... Gilgamesh

The tavern-keeper Siduri who lives by the seashore,

she lives...

the pot-stand was made for her, the golden fermenting vat was made

for her.

She is covered with a veil ...

Gilgamesh was roving about...

wearing a skin,...

having the flesh of the gods in his body,

but sadness deep within him,

looking like one who has been traveling a long distance.

The tavern-keeper was gazing off into the distance,

puzzling to herself, she said,

wondering to herself:

"That fellow is surely a murderer(!)!

26 The Epic of Gilgamesh, Tablet X, URL: www.ancienttexts.org/library/mesopotamian/Gilgamesh/tab10.htm, occessed 16.2.2017. סלים, לקחתי תרגום מקובל באנגלית, במקום לתרגם מערבית מיכאל 
Where is he heading! ..."

As soon as the tavern-keeper saw him, she bolted her door, bolted her gate, bolted the lock.

But at her noise Gilgamesh pricked up his ears, lifted his chin (to look about) and then laid his eyes on her.

Gilgamesh spoke to the tavern-keeper, saying:

"Tavern-keeper, what have you seen that made you bolt

your door,

bolt your gate, bolt the lock!

if you do not let me in I will break your door, and smash

the lock!

... the wilderness."

... Gilgamesh

... gate

Gilgamesh said to the tavern-keeper:

"I am Gilgamesh, I killed the Guardian!

I destroyed Humbaba who lived in the Cedar Forest,

I slew lions in the mountain passes!

I grappled with the Bull that came down from heaven, and

killed him."

The tavern-keeper spoke to Gilgamesh, saying:

"lf you are Gilgamesh, who killed the Guardian,

who destroyed Humbaba who lived in the Cedar Forest,

who slew lions in the mountain passes,

who grappled with the Bull that came down from heaven, and

killed him,

why are your cheeks emaciated, your expression desolate!

Why is your heart so wretched, your features so haggard!

Why is there such sadness deep within you!

Why do you look like one who has been traveling a long

distance

so that ice and heat have seared your face!

... you roam the wilderness!"

In this passage from the original myth Gilgamesh arrives at Siduri's tavern. Siduri is frightened and bolts the door, but Gilgamesh threatens her, boasting that he is the great Gilgamesh who killed the wild beasts and that if she did not open the door he would smash the tavern. Siduri asks him why his features are emaciated and he appears haggard. We can observe differences and similarities between the two poetic passages quoted above and this mythological text. At the beginning of the scene Gilgamesh is described in terms similar to those in the legend where, however, Siduri neither welcomes nor recognizes Gilgamesh, quite the contrary, in fact. The same is true of Gilgamesh's admiration for the tavern and his talk about women. Why, then, does Yūsuf present some details as they appear in the original myth while changing many others? The answer lies in his desire to fit the meanings to his aim. In this sense his use of the myth in his poetry is not incidental, but is utilized for expressing new, contemporary meanings, among them meanings associated with psychological drama. 
In the second passage of the first scene we read:27

Gilgamesh:

How did you recognize me

Although I am disheveled, dusty and with a parched face

Wearing hides

And living in a remote place?

Siduri:

A woman will never escape you, 0 Gilgamesh)

(Hands him a cup)

Gilgamesh:

(Sips a bit) But I let one woman escape ...

Siduri:

What woman, 0 Gilgamesh?

Gilgamesh:

The one called "Life" in the tablets

Siduri:

You are still obstinate

You did not learn from Enkidu's tears

In these lines Gilgamesh expresses his wonder at the fact that Siduri recognizes him despite the tatters he wears and the other signs of his journey. Siduri replies that no woman escaped Gilgamesh. After she gives him a cup of wine and he sips from it, he tells her that one woman escaped him, the woman he symbolically calls "Life". It is clear that there are missing events here or, in other words, there are semicircles in this dialogue, as we called them above. One semicircle is Gilgamesh's declaration "but I let one woman escape", but its counterpart is missing; we may surmise that the missing part consists of the following text from the first and second column in the original myth of Gilgamesh:

Gilgamesh does not leave a son to his father,

day and night he arrogant[y(?) ...

Is Gilgamesh the shepherd of Uruk-Haven,

is he the shepherd....

bold, eminent, knowing, and wise!

Gilgamesh does not leave a girl to her mother(?)

The daughter of the warrior, the bride of the young man ${ }^{28}$

From the text of the original myth it would appear that Gilgamesh left no virgin whom he did not force to wed him, so it is no wonder that Siduri recognized him. In the above-quoted passage we learn of Gilgamesh's first mental fall, in the form of an imaginary woman who felled him, after he had felled all the women in the world; this woman, who overpowered him, was life. In this way we are led into the protagonist's psyche and are able to follow the suffering his experiences as a result of his "death complex".

From this we conclude that the Iraqi poet Sa'dī Yūsuf used psychological drama and within the framework of this genre maintained a dialogue with an ancient Iraqi myth, in order to express

27 Yūsuf, 1992, 118.

28 The Epic of Gilgamesh, Tablet I, URL:

http://www.ancienttexts.org/library/mesopotamian/gilgamesh/tab1.htm, accessed 17.2.2017. 
the mental struggles of Iraqis as symbolized by Gilgamesh, the struggles of confused individuals searching for salvation.

\section{References}

Al-Aḥmad, Sāmī Sa'īd (1982). Al-Madkhal ilā tārīkh al-călam al-qadìm, Part Two. Baghdad: no publisher's name. 'Alī, 'Awwād (1997). Ghawāyat al-mutakhayyil al-masrahị. Casablanca: al-Markaz al-thaqāfĩ al-'arabī.

'Anānī, Muhammad (1985). Al-Masraḥ wal-shi'r. Cairo: Maktabat Ghurayyib.

Badaj, Wālis (1999). Al-Diyāna al-fir'awniyya. Amman: Azmina lil-nashr wal-tawzīc .

Badawī, 'Abduh (1998). Dirāsāt fì al-nașs al-shi' rī. Cairo: Dār qibā’.

Bāwarz, Fūbiyūn (1990). Al-Masraḥ fi al-sharq. Sharja: Markaz al-Shāriqa lil-ibdāc al-fannī.

Al-Dālī, Ibrāhīm (1999). Al-Adab al-masraḥī al-mu'āṣir. Cairo: 'Ālam al-kutub.

Al-Ghadhdhāmī, 'Abdullāh (1993). Al-Khațīa wal-takfirr. Kuwait: Dār Su'ād al-Ṣabāḥ.

Ghanaim, Mahmmūd (1987). "al-Qasriyyāt al-naw'iyya fī riwāyāt tayyār al-wa'y", al-Karmil 12, 69-103.

Hāijj, Ḥannā Nūr (2002). Al-Masrah fi mir mirāt dhātihi. Haifa University: Faculty of the Humanities.

Ḥammūda, 'Abd al-'Azīz (1999). "al-Masrah fị al-mashriq al-'arabī al ḥadīth", in: al-Hawiyya al-qawmiyya fĩ al-adab al-'arabī, silsilat maqālät, 383-401.

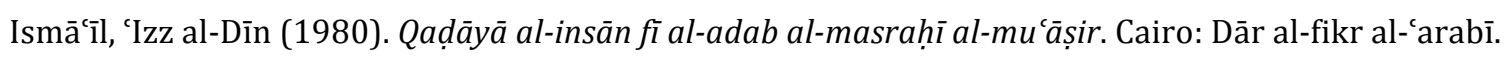

Makkāwī, 'Abd al-Ghaffār (1995). Shi'r wa-fikr. Cairo: al-Hay’a al-mișriyya al-āmma lil-kitāb.

Al-Nādī, 'Ādil (1987). Fann kitābat al-drāmā. Tunis: Mu’assasāt 'Abd al-Karīm 'Abdullāh.

Sallūm, Dāwūd (1977-1987). Qaḍāyā adabiyya 'irāqiyya. Baghdad: al-Ittihād al-'arabī lil-țibāáa.

Sartre, Jean-Paul (2008). סלים, אתה חייב לתת מקור אנגלי של ספרים שיצאו לאור באנגלית

Al-Sawwāḥ, Firās (2002). Gilgamesh, malhamat al-rāfidayn al-khālida. Damascus: Manshūrāt 'Alā’ al-Dīn.

Shukrī, Ghālī (1965). Thawrat al-fikr fĩ adabinā al-ḥadīth. Cairo: The Anglo-Egyptian Library.

Șulayḥa, Nihād (1982). Al-Tayyārāt al-masrahiyya al-mu'āṣira. Sharja: Markaz al-Shāriqa lil-ibdāe al-fikrī.

Al-Ṭabarī, Abū Jacfar Muḥammad b. Jarīr. Tafsīr al-Tabarī, vol. I. Beirut: Dār al-kutub al-ilmiyya.

Yūsuf, Sa'dī (1992). Qașā’id Bārīs, shajar İthākā. Germany: Manshūrāt al-jamal. 